\title{
Genetic Diversity of avrBs-like Genes in Three Different Xanthomonas Species Isolated in Korea
}

\author{
Chang-Sik Oh ${ }^{1,3}$, Seungdon Lee ${ }^{2}$ and Sunggi Heu ${ }^{1 *}$ \\ ${ }^{1}$ Microbial Safety Division, National Academy of Agricultural Science, RDA, Suwon 441-707, Korea \\ ${ }^{2}$ Research Coordination Division, RDA, Suwon 441-707, Korea \\ ${ }^{3}$ Department of Horticultural Biotechnology, Kyung Hee University, Yong-In 446-701, Korea \\ (Received on October 19, 2010; Accepted on December 15, 2010)
}

\begin{abstract}
Plant-pathogenic bacteria including Xanthomonas spp. carry genetic diversity in composition of avirulence genes for interaction with their host plants. Previously, we reported genetic diversity of avirulence genes in $X$. axonopodis pv. glycines. In this study, we determined genetic diversity of five avirulence genes, avrBs $1, a v r B s 2$, $a v r B s 3$, avrBs 4 , and $a v r R x v$, in three other Xanthomonas species isolated in Korea by genomic southern hybridization. Although Korean races of $X$. campestris pv. vesicatoria that were isolated from year 1995 to 2002 had the same avirulence gene patterns as those that already reported, there was race shift from race 3 to race 1 by acquisition of avrBs3 genes. $X$. campestris pv. campestris isolated from Chinese cabbage, but not from cabbage or radish, carried two avrBs3 genes, and one of them affected HR-eliciting ability of this bacterium in broccoli. $X$. oryzae pv. oryzae carried eight to thirteen avrBs3 gene homologs, and this bacterium showed dynamic changes of resistance patterns in rice probably by losing or obtaining avrBs3 genes. These results indicate that avrBs3 gene is more diverse in Xanthomonas spp. than other four avirulence genes and also host ranges of these bacteria can be easily changed by loss or acquisition of avrBs3 genes.
\end{abstract}

Keywords : avrBs3, Xanthomonas campestris pv. campestris, Xanthomonas oryzae pv. oryzae, host range

Gram-negative plant pathogenic bacteria, including Xanthomonas species, deliver many effector proteins into plant cells through the type III secretion system (T3SS) (Alfano and Collmer, 2004). Those effector proteins have been shown to manipulate host defense signaling pathways, by targeting and interfering with certain plant proteins. One group of bacterial effector proteins is transcription activator-like (TAL) effectors. They act like plant transcription factors and directly control expression of plant genes by

\footnotetext{
*Corresponding author.

Phone) +82-31-290-0420, FAX) +82-31-290-0406

E-mail)heu@rda.go.kr
}

targeting to the plant nucleus (Kay et al., 2007). The best well-characterized TAL effector is AvrBs3 protein from $X$. campestris pv. vesicatoria, causing bacterial spot disease on tomato and pepper (Schornack et al., 2006).

The avrBs3 gene in X. campestris pv. vesicatoria originally cloned from strain $71-21$ is a single copy gene that encodes a protein with three distinct domains (Bonas et al., 1989). AvrBs3 protein has two nuclear localization signals and transcriptional activation domain in its C-terminus (Van den Ackerveken et al., 1996). It also has 17.5 times of 34 amino acid repeats in its central region. This repeat region has been shown to be critical for protein dimerization and DNA binding activity of AvrBs3 (Schornack et al., 2006). AvrBs3 protein causes hypertrophy of plant mesophyll cells that may help bacterial release to the plant leaf surface in the late stage of infection. Hypertrophy by AvrBs3 protein results from induced expression of certain plant genes with UPA (upregulated by AvrBs3) box in their promoters such as UPA20 gene (Kay et al., 2007). The resistance pepper cultivars to $X$. campestris pv. vesicatoria strains carrying $a v r B s 3$ gene contain a corresponding resistance gene, $B s 3$. This gene encodes a putative flavin monooxygenase, and its expression is controlled by the promoter with UPA box (Romer et al., 2007). The function of Bs3 protein is not clear, but Bs3-mediated resistance is triggered by recognition of UPA box by AvrBs3, resulting in induction of the hypersensitive response (HR). X. campestris pv. vesicatoria has a AvrBs3 homolog, AvrBs4, which has very similar domain structures and is recognized by Bs4 resistance protein (Schornack et al., 2004).

Other Xanthomonas species such as $X$. oryzae and $X$. axonopodis have been shown to contain avrBs 3 gene homologs (Kay and Bonas, 2009; Schornack et al., 2006). In particular, $X$. oryzae pv. oryzae causing bacterial leaf blight on rice and $X$. axonopodis pv. citri causing bacterial canker on citrus plants have multiple AvrBs3 homologs. Among them, AvrXa7 and AvrXa27 of X. oryzae pv. oryzae and PthA of $X$. axonopodis pv. citri have been relatively well characterized, and all contribute to bacterial pathogeni- 
city on each host plant (Gu et al., 2005; Swarup et al., 1992; Yang and White, 2004; Yang et al., 2000). Previously, we reported that $X$. axonopodis pv. glycines strains causing bacterial pustule disease on soybean carry three to seven $a v r B s 3$ gene homologs, based on genomic southern hybridization with 155 strains isolated in Korea (Park et al., 2008). We also reported that $X$. axonopodis pv. glycines strains carry a single copy of avrBs 2 gene, but neither avrBs 1 nor $a v r R x v$.

$X$. campestris pv. vesicatoria has been shown to carry more than 15 genes, including $a v r B s 1$, avrBs 2, and $a v r R x v$, that encode effector proteins (Kay and Bonas, 2009). avrBs 1 and $a v r B s 2$ genes are critical avirulence genes to determine races of $X$. campestris pv. vesicatoria, along with avrBs3 gene. Initially, pepper races of this bacterium were determined based on HR induction in pepper ECW differential cultivars carrying $B s 1, B s 2$, or $B s 3$ resistance genes (Jones and Stall, 1998). For example, while pepper race 1 including the strain 71-21 induces the HR in both ECW-20R and ECW-30R because it carries both $a v r B s 2$ and $a v r B s 3$ genes, pepper race 2 induces the HR in both ECW-10R and ECW20R because it carries both $a v r B s 1$ and $a v r B s 2$ genes. Pepper race 3 induces the HR only in ECW-20R because it carries only avrBs 2 gene. While the function of AvrBs1 protein is still unknown, AvrBs2 protein is a putative glycerophosphoryldiester phosphodiesterase (Swords et al., 1996). AvrRxv that encodes a putative cysteine protease or acetyltransferase belongs to YopJ/AvrRxv protein family (Ciesiolka et al., 1999).

In this study, we examined genetic diversity of five avirulence genes, $a v r B s 1, a v r B s 2, a v r B s 3, a v r B s 4$, and $a v r R x v$ in three Xanthomonas species isolated in Korea by genomic southern hybridization. We show race shift by uptake of avrBs 3 genes in $X$. campestris pv. vesicatoria and X. oryzae pv. oryzae within a short time period. In addition, we show that $X$. campestris pv. campestris strains isolated from Chinese cabbage carry two $a v r B s 3$ genes, and one of them affects recognition of this bacterium in broccoli.

\section{Materials and Methods}

Bacterial strains. Bacterial strains of $X$. campestris pv. vesicatoria and $X$. oryzae pv. oryzae were isolated from pepper and rice, respectively, grown in Korea during year 1995 to 2003. X campestris pv. campestris strains were isolated from Chinese cabbage, cabbage or radish grown in Korea during the same years. All strains collected were first tested for HR using nonhost plant, tobacco. Identities of all strains were confirmed by determining compositions of fatty acid methyl esters (FAME) with gas chromatography and also by using Biolog identification system (Bio-Rad, CA, USA), according to the manufacturer's instructions.
Bacterial strains were preserved in at $-80^{\circ} \mathrm{C}$ for long-term storage, retrieved from the stock and were not transferred more than 2 or 3 times before testing pathogenicity.

Xanthomonas spp. were grown in peptone-sucrose agar (PSA) for 2 days at $28^{\circ} \mathrm{C}$ and Escherichia coli was grown in LB medium at $37^{\circ} \mathrm{C}$. The concentrations of antibiotics incorporated into media were as follows: rifampicin, $50 \mathrm{ug} /$ $\mathrm{ml}$; kanamycin, $50 \mathrm{ug} / \mathrm{ml}$; tetracycline, $15 \mathrm{ug} / \mathrm{ml}$; ampicillin, $50 \mathrm{ug} / \mathrm{ml}$.

Genomic southern hybridization. Southern hybridization was performed as described previously (Park et al., 2008). Briefly, total genomic DNA digested with BamHI was electrophoresed in $0.7 \%$ agarose gel, depurinated with 0.25 $\mathrm{N} \mathrm{HCl}$ for $15 \mathrm{~min}$ and transferred onto nylon membrane (GE Healthcare, NJ, USA) using vacuum blotter (BioRad). The transferred DNA was crossed linked on the membrane with UV for $3 \mathrm{~min}$. The dried membrane was prehybridized with hybridization solution [5X SSC, N-laurylsarcosine, $0.1 \%$ (W/V); SDS, 0.2\% (W/V); Blocking reagent, $1 \%(\mathrm{~W} /$ $\mathrm{V})$ ] at $68^{\circ} \mathrm{C}$ for $1 \mathrm{hr}$. Hybridization was performed with fresh $10 \mathrm{ml}$ hybridization solution with denatured gene probes for $100 \mathrm{~cm}^{2}$ of membrane at $68^{\circ} \mathrm{C}$ for $16 \mathrm{hrs}$.

For the preparation of the probes for $\operatorname{avrBs} 1, \operatorname{avrBs} 2$, and $a v r R x v$, DNA fragments of $1.2 \mathrm{~kb}, 2.1 \mathrm{~kb}$, and $1.1 \mathrm{~kb}$, respectively, were amplified and cloned into pTOPO cloning vector by using the following primer pairs: BS1F (5'ATGTCCGACATGAAAGTTAATTTC-3') and BS1R (5'TCTCCTGCATTTGTAACATG-3') for $a v r B s 1$; BS2F (5'CGCGTATAGGTCCTCCGCAAC-3') and BS2R (5'CAATCCGGCTCGGTCTGGTTG-3') for $a v r B s 2$; RXVF (5'-TATGRGCGACTCCATAAGAG-3') and RXVR (5'CTCAGCGCGCCGAGTCGCGCGG-3') for $a v r R x v$. For the gene probe of both $a v r B s 3$ and $a v r B s 4$, the plasmid pBSavrXa10 containing avrXal0, one of avrBs3 gene homologs of $X$. oryzae in the pBluescript II KS+ vector was used (Hopkins et al., 1992). Each gene probe was labeled by using the Megaprime DNA labeling kit (GE Healthcare).

Mutagenesis of avrBs3 gene homolog in $X$. campestris pv. campestris. To mutate avrBs 3 homolog in $X$. campestris pv. campestris, avrXa10 in the plasmid, pBSavrXa10, was first mutated in vitro by using EZ::Tn Km transposon kit (EPICENTRE, WI, USA). The plasmid, in which EZ::Tn $\mathrm{Km}$ was inserted in avrXal0 gene, was screened and confirmed by DNA sequencing. The resultant plasmid was transformed into $X$. campestris pv. campestris strain 1175 isolated from Chinese cabbage by Gene Pulser (Bio-Rad) for mutation of $a v r B s 3$ gene homolog based on double crossover recombination. Putative mutants were selected on LB agar supplemented with rifampicin, kanamycin, and ampicillin. To verify that double crossover had occurred in 
avrBs3 gene homolog $X$. campestris pv. campestris strain 1175, selected putative mutants were confirmed by genomic southern hybridization with $a v r B s 10$ gene probe.

Disease and HR assays. For disease assay in crucifer plants, $10^{8} \mathrm{CFU} / \mathrm{ml}$ of $X$. campestris pv. campestris isolated from Chinese cabbage, cabbage, or radish was inoculated by spraying bacterial suspension. With rice monogenic lines, $X$. oryzae pv. oryzae strains were inoculated by cutting the top edge of leaves by scissors after dipping into bacterial suspension $\left(10^{8} \mathrm{CFU} / \mathrm{ml}\right)$. Inoculated plants were kept at the greenhouse for 5 days for $X$. campestris pv. campestris and for 10 days for $X$. oryzae pv. oryzae and the disease severity was scored by the lesion length $(\mathrm{cm})$. For HR assay, $10^{8}$ $\mathrm{CFU} / \mathrm{ml}$ of $X$. campestris pv. campestris wild type and mutant strains was infiltrated in broccoli leaves by needleless syringe. HR was scored 24 hours after infiltration.

\section{Results}

Genetic diversity of five avirulence genes in $X$. campestris pv. vesicatoria strains isolated in Korea. Races of $X$. campestris pv. vesicatoria are determined, based on presence of $\operatorname{avrBs} 1, \operatorname{avrBs} 2$, or $a v r B s 3$ genes, as described in Introduction. We first determined if this general pattern is conserved in strains isolated in Korea from year 1995 to 2002 by southern hybridization with gene probes of $a v r B s 1$, $a v r B s 2$, and $a v r B s 3$ originated from the American strains 85-10 (pepper race 2) and 71-21 (pepper race 1). We also checked two more avirulence genes, avrBs 4 and $a v r R x v$. Southern results showed that Korean race 1 of $X$. campestris pv. vesicatoria carries four avirulence genes except avrBsl, and Korean race 3 carries three avirulence genes except $a v r B s 1$ and $a v r B s 3$, as summarized in Fig. 1A. This pattern was the same as reported in American strains.

We further examined the presence of $a v r B s 3$ gene and its homolog avrBs 4 in 15-20 individual strains from year 1995 to 2002. We grouped strains from year 1995 to 1998, year 1999 to 2000, and year 2001 to 2002. From this assay, we found that only a few strains from year 1995-1998 carried the $a v r B s 3$ gene, but the number of strains dramatically increased during 2001-2002 (Fig. 1B). In contrast, distribution of the avrBs 4 gene was not changed significantly. These results indicate that there was race shift from race 3 to race 1 due to uptake of the $a v r B s 3$ gene.

Genetic diversity of four avirulence genes in $X$. campestris pv. campestris strains isolated from three different crucifer plants in Korea. Previously it was shown that $X$. campestris pv. campestris carries avrBs 1, avrBs2, and $a v r R x v$, but not avrBs3 gene (Kay and Bonas, 2009). We isolated 47 strains from three different crucifer plants: 27 from Chinese cabbage, 14 from cabbage, and 6 from radish. We examined the presence of four avirulence genes by southern hybridization in these strains. Southern results showed that $a v r B s 2$ was present in all strains, but $a v r R x v$ was not (Fig. 2A). More interestingly, $a v r B s 1$ was only present in strains isolated from cabbage, but not from Chinese cabbage or radish. In addition, $a v r B s 3$ gene was present in strains only isolated from Chinese cabbage, but not from cabbage or radish, and two different copies were detected (Fig. 2A and 2B). These results indicate that $a v r B s 3$ genes are present in

A

\begin{tabular}{cccccc}
\hline & \multicolumn{5}{c}{ Homology with } \\
\cline { 2 - 6 } Xcv & avrBs1 & avrBs2 & avrBs3 & avrBs4 & avrRxv \\
\hline Race 1 & - & + & + & + & + \\
Race 3 & - & + & - & + & + \\
\hline
\end{tabular}

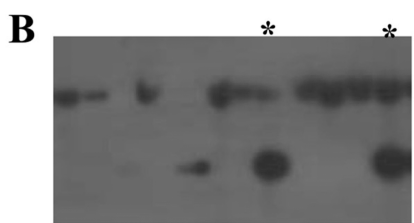

1995 1998

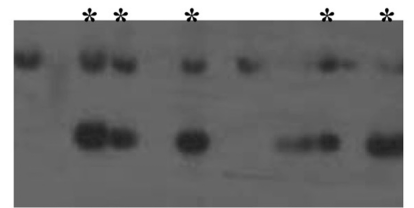

1999 2000

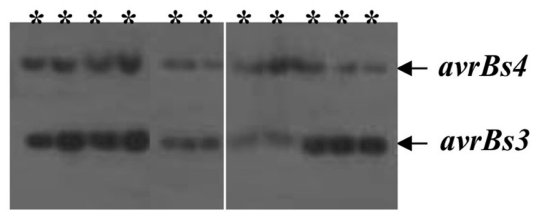

$2001 \sim 2002$

Fig. 1. Genetic diversity of five avirulence genes in $X$. campestris pv. vesicatoria $(X c v)$ isolated in Korea by genomic southern hybridization. (A) Summary of genomic southern hybridization with race 1 and race 3 by using gene probes of five avirulence genes indicated in the figure. + and - indicate the presence and absence of indicated genes, respectively. (B) Southern hybridization of 11-12 different strains isolated in each indicated year period, using gene probes of avrBs3. Since avrBs3 and $a v r B s 4$ share $97 \%$ sequence identity and only two bands were detected, the bigger band was indicated as an avrBs 4 homolog. * indicates strains that belong to race 1 . 
A

\begin{tabular}{ccccc}
\hline & \multicolumn{5}{c}{ Homology with } \\
\cline { 2 - 5 }$X c c$ isolated from & avrBs1 & avrBs2 & avrBs3 & avrRxv \\
\hline Chinese cabbage & - & + & + & - \\
Cabbage & + & + & - & - \\
Radish & - & + & - & - \\
\hline
\end{tabular}

B

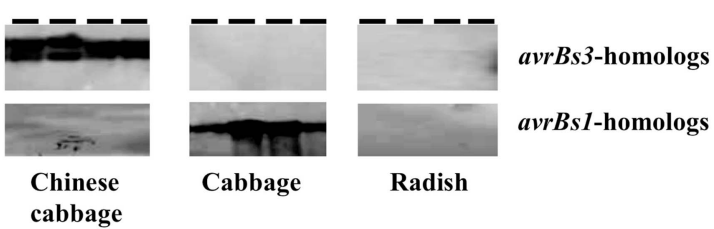

Fig. 2. Genetic diversity of four avirulence genes in $X$. campestris pv. campestris $(X c c)$ isolated from three crucifer plants in Korea by genomic southern hybridization. (A) Summary of genomic southern hybridization with 27 strains from Chinese cabbage, 14 strains from cabbage and 6 strains from radish. + and - indicate the presence and absence of indicated genes, respectively. (B) Southern hybridization of 4 representative strains isolated from each plant, using gene probes of $a v r B s 1$ and $a v r B s 3$.

$X$. campestris pv. campestris strains originated from certain host plants, and avrBs 1 or avrBs3 genes may affect host range of this bacterium.

To determine host range of $X$. campestris pv. campestris strains, we tested disease development in six different crucifer plants, as shown in Table 1. The strains isolated from radish were highly virulent only in radish roots. While the $a v r B s 3$-carrying strains isolated from Chinese cabbage were highly virulent in Chinese cabbage, cabbage, chingensai, and rae rape, the avrBs l-carrying strains isolated from cabbage were highly virulent in cabbage, chingensai and broccoli. These results indicate that avrBs 1 and $a v r B s 3$ genes affect their host ranges.

An avrBs3 gene in $X$. campestris pv. campestris strains isolated from Chinese cabbage acts like a host range

Table 1. Disease severity of crucifers infected by $X$. campestris pv. campestris $(X c c)$ isolated from different host plants

\begin{tabular}{lccc}
\hline \hline \multirow{2}{*}{ Crucifers } & \multicolumn{3}{c}{ Xcc isolated from } \\
\cline { 2 - 4 } & Chinese cabbage & Cabbage & Radish \\
\hline Chinese cabbage & $+++++^{\mathrm{a}}$ & ++ & + \\
Cabbage & +++++ & +++++ & - \\
Chingensai & +++++ & +++++ & + \\
Rae Rape & +++++ & + & - \\
Broccoli & - & +++++ & - \\
Radish (Leaf) & + & ++ & - \\
Radish (Root) & + & + & +++++ \\
\hline
\end{tabular}

${ }^{a}$ the amount of disease severity: +++++ , highly virulent; ++ or + , marginally virulent; - , avirulent
A

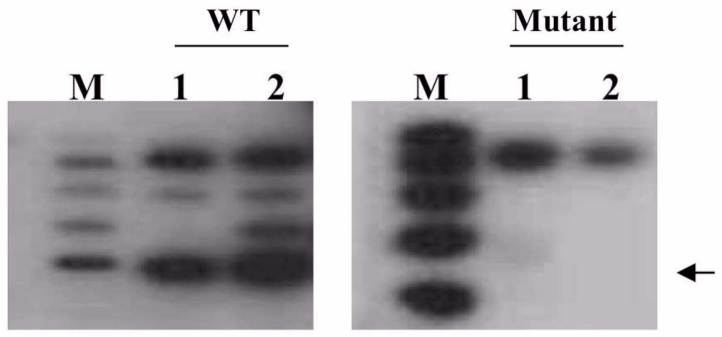

B

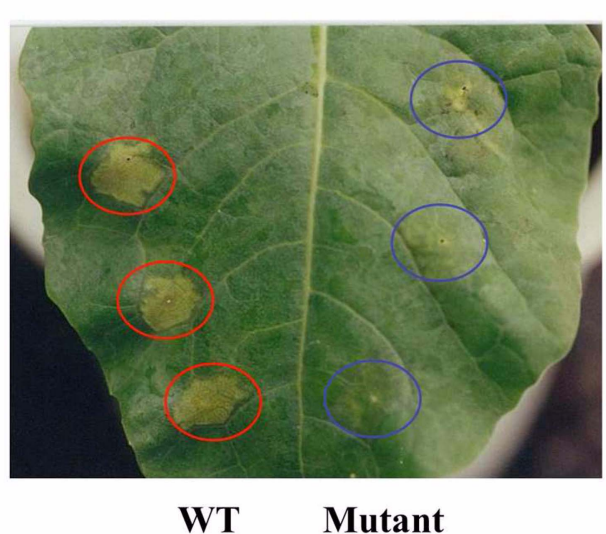

Fig. 3. Analysis of Chinese cabbage strain of $X$. campestris pv. campestris mutated in one of two avrBs 3 gene homologs. (A) Southern hybridization of two wild type (WT) and two mutant strains using avrBs 3 gene probe. Arrow indicates the mutated gene of $a v r B s 3$ homolog. (B) HR assay in broccoli using the wild type (red circles) and mutant strain (blue circles).

determinant. From disease assay shown in Table 1, we found that strains from cabbage were highly virulent, but strains from Chinese cabbage were completely avirulent in broccoli. To determine if $a v r B s 3$ genes present in strains isolated from Chinese cabbage affect this phenotypic difference, we mutated one of two avrBs3 genes in two strains isolated from Chinese cabbage, by using the avrXa10::EZ::Tn, as described in Materials and Methods. As shown in Fig. $3 \mathrm{~A}$, the bottom band of $a v r B s 3$ genes was disappeared in mutant strains. We tested if this mutation affects HR induction in broccoli, compared to the wild type. While the wild type induced a strong HR in broccoli, the mutant did not (Fig. 3B), indicating that broccoli can recognize AvrBs3 of strains from Chinese cabbage and this recognition makes this strain avirulent in broccoli.

Genetic diversity of avrBs3 genes in X. oryzae pv. oryzae strains isolated from rice in Korea. Previously it was shown that $X$. oryzae pv. oryzae carries avrBs 2 and avrBs3, but neither avrBs1 nor avrRxv (Kay and Bonas, 2009). We isolated 78 strains from rice in Korea and examined if they carry those four genes by genomic southern hybridization. Interestingly, all strains carried only avrBs3 genes (Fig. 4A), and the number of $a v r B s 3$ genes varied eight to thirteen 


\begin{tabular}{ccccc} 
& \multicolumn{4}{c}{ Homology with } \\
\cline { 2 - 5 } Pathogen & avrBs1 & avrBs2 & avrBs3 & avrRxv \\
\hline Xoo & - & - & + & - \\
\hline
\end{tabular}

B

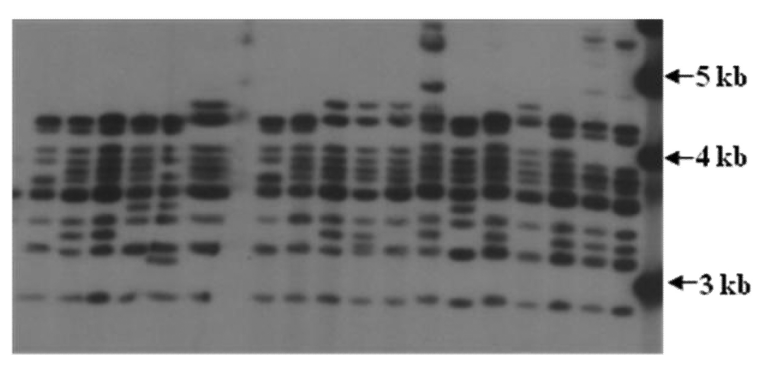

Fig. 4. Genetic diversity of four avirulence genes in X. oryzae pv. oryzae $(\mathrm{Xoo})$ isolated in Korea by genomic southern hybridization. (A) Summary of genomic southern hybridization with 78 strains isolated nationwide of Korea by using gene probes of four avirulence genes indicated in the figure. + and - indicate the presence and absence of indicated genes, respectively. (B) Southern hybridization of 18 different strains using avrBs 3 gene probe.

among strains (Fig. 4B). Previously, we reported that $X$. axonopodis pv. glycines strains have three to seven of $a v r B s 3$ genes (Park et al., 2008). The variation of avrBs 3 genes in
$X$. oryzae pv. oryzae was higher than $X$. axonopodis pv. glycines and two other Xanthomonas bacteria described above.

Using nine different rice monogenic lines (Huang et al., 1997), we further determined disease resistance patterns of $X$. oryzae pv. oryzae strains isolated for four years (year 1999 to 2003). We found that resistance phenotype was broken down by appearance of new races of $X$. oryzae pv. oryzae, because resistance mediated by dominant resistance genes, Xa1, Xa3, Xa7, and Xa8, was overcome by some strains in year 2002, 2001, 2001, and 2003, respectively (Table 2). In addition, we also found that some strains obtained avirulence genes recognized by xa13 in year 2003 . In contrast, resistance mediated by a recessive resistance gene, xa5, was not broken down by any strains tested in our study. These results indicate that $X$. oryzae pv. oryzae strains lose their own avirulence genes or obtain new avirulence genes within a short time period to modulate interaction with host plants.

\section{Discussion}

In this study, we have shown that Xanthomonas spp. carry dynamic genetic diversity in composition of avirulence genes, and diversity of $a v r B s 3$ gene among or within species is very high. In addition, we have shown that Xanthomonas

Table 2. Responses of rice monogenic lines to X. oryzae pv. oryzae strains isolated in year 1999-2003

\begin{tabular}{|c|c|c|c|c|c|c|c|c|c|c|}
\hline \multirow[b]{2}{*}{ Year } & \multirow[b]{2}{*}{ Strains \# } & \multicolumn{9}{|c|}{ Rice monogenic lines } \\
\hline & & $\begin{array}{c}\text { IRBB1 } \\
\text { (Xa1) }\end{array}$ & $\begin{array}{c}\text { IRBB3 } \\
\text { (Xa3) }\end{array}$ & $\begin{array}{c}\text { IRBB4 } \\
\text { (Xa4) }\end{array}$ & $\begin{array}{c}\text { IRBB5 } \\
\text { (xa5) }\end{array}$ & $\begin{array}{c}\text { IRBB7 } \\
\text { (Xa7) }\end{array}$ & $\begin{array}{c}\text { IRBB8 } \\
\text { (Xa8) }\end{array}$ & $\begin{array}{c}\text { IRBB10 } \\
\text { (Xa10) }\end{array}$ & $\begin{array}{c}\text { IRBB13 } \\
\text { (xa13) }\end{array}$ & $\begin{array}{c}\text { IRBB21 } \\
\text { (Xa21) }\end{array}$ \\
\hline \multirow[t]{4}{*}{1999} & 1917 & $\mathrm{R}$ & $\mathrm{R}$ & $\mathrm{S}$ & $\mathrm{R}$ & $\mathrm{R}$ & $\mathrm{R}$ & $\mathrm{S}$ & $\mathrm{S}$ & $\mathrm{R}$ \\
\hline & 1918 & $\mathrm{R}$ & $\mathrm{R}$ & $\mathrm{R}$ & $\mathrm{R}$ & $\mathrm{R}$ & $\mathrm{R}$ & S & S & $\mathrm{S}$ \\
\hline & 1919 & $\mathrm{R}$ & $\mathrm{R}$ & $\mathrm{R}$ & $\mathrm{R}$ & $\mathrm{R}$ & $\mathrm{R}$ & S & S & $\mathrm{R}$ \\
\hline & 1920 & $\mathrm{R}$ & $\mathrm{R}$ & S & $\mathrm{R}$ & $\mathrm{R}$ & $\mathrm{R}$ & $\mathrm{S}$ & S & $\mathrm{R}$ \\
\hline \multirow[t]{4}{*}{2001} & 2122 & $\mathrm{R}$ & S* & S & $\mathrm{R}$ & $\mathrm{R}$ & $\mathrm{R}$ & $S$ & $\mathrm{~S}$ & $S$ \\
\hline & 2123 & $\mathrm{R}$ & $\mathrm{S}^{*}$ & $\mathrm{~S}$ & $\mathrm{R}$ & $\mathrm{R}$ & $\mathrm{R}$ & S & $\mathrm{S}$ & $\mathrm{S}$ \\
\hline & 2124 & $\mathrm{R}$ & $\mathrm{S}^{*}$ & S & $\mathrm{R}$ & $\mathrm{R}$ & $\mathrm{R}$ & $\mathrm{S}$ & S & $\mathrm{S}$ \\
\hline & 2125 & $\mathrm{R}$ & $\mathrm{R}$ & S & $\mathrm{R}$ & $S^{*}$ & $\mathrm{R}$ & S & S & $\mathrm{R}$ \\
\hline \multirow[t]{4}{*}{2002} & 2235 & $\mathrm{R}$ & $\mathrm{R}$ & $\mathrm{R}$ & $\mathrm{R}$ & $\mathrm{R}$ & $\mathrm{R}$ & $S$ & $S$ & $\mathrm{~S}$ \\
\hline & 2236 & $\mathrm{R}$ & $\mathrm{S}$ & $\mathrm{S}$ & $\mathrm{R}$ & $\mathrm{S}$ & $\mathrm{R}$ & $\mathrm{S}$ & S & $\mathrm{S}$ \\
\hline & 2237 & $\mathrm{R}$ & $\mathrm{R}$ & $\mathrm{S}$ & $\mathrm{R}$ & $\mathrm{S}$ & $\mathrm{R}$ & $\mathrm{S}$ & $\mathrm{S}$ & $\mathrm{S}$ \\
\hline & 2238 & $\mathrm{~S}^{*}$ & $\mathrm{~S}$ & $\mathrm{R}$ & $\mathrm{R}$ & $\mathrm{R}$ & $\mathrm{R}$ & $\mathrm{S}$ & S & $\mathrm{R}$ \\
\hline \multirow[t]{4}{*}{2003} & 2345 & $\mathrm{R}$ & $\mathrm{S}$ & $\mathrm{R}$ & $\mathrm{R}$ & $\mathrm{R}$ & $\mathrm{R}$ & $\mathrm{S}$ & $\mathrm{R} * *$ & $\mathrm{~S}$ \\
\hline & 2346 & $\mathrm{R}$ & $\mathrm{R}$ & $\mathrm{S}$ & $\mathrm{R}$ & $\mathrm{R}$ & $\mathrm{R}$ & $\mathrm{S}$ & $\mathrm{R} * *$ & $\mathrm{R}$ \\
\hline & 2347 & $\mathrm{~S}$ & $\mathrm{R}$ & $\mathrm{R}$ & $\mathrm{R}$ & $\mathrm{R}$ & $\mathrm{S}^{*}$ & $\mathrm{~S}$ & S & $\mathrm{R}$ \\
\hline & 2348 & $\mathrm{R}$ & $\mathrm{S}$ & $\mathrm{S}$ & $\mathrm{R}$ & $\mathrm{S}$ & $\mathrm{R}$ & $\mathrm{S}$ & $\mathrm{R} * *$ & $\mathrm{~S}$ \\
\hline
\end{tabular}

$\mathrm{R}$, resistant; $\mathrm{S}$, susceptible

*: appearance of susceptible strains, compared to the previous year

**: appearance of resistant strains, compared to the previous year 
spp. can easily lose or obtain $a v r B s 3$ genes and change their host ranges within a short time period. In particular, this characteristic was apparent in $X$. oryzae pv. oryzae because each strain of this bacterium carries different numbers of avrBs3-like genes and many of them carry both virulence and avirulence activities in host plants, as reported (NinoLiu et al., 2006).

AvrBs3 and its homologs are highly homologous, but they have various numbers of 34 or 35 amino acids tandem repeats in their central regions, which have been shown to determine their specificity. Within 34 amino acids in each repeat, $12^{\text {th }}$ and $13^{\text {th }}$ amino acids are highly variable (Boch et al., 2009). Recently, two papers have showed that these two highly variable amino acids in each repeat determine target DNA base specificity and they bind to each base in UPA box that locates in the promoter region of genes regulated by AvrBs3 and its homologs (Boch et al., 2009; Moscou and Bogdanove, 2009). Based on southern hybridization, $X$. oryzae pv. oryzae carries eight to thirteen different $a v r B s 3$ gene homologs, and they look like a ladder (Fig. 4B). This may indicate that these AvrBs3 homologs have various numbers of tandem repeats, and their DNA target specificity is very likely different. In addition, due to high homology among avrBs3 gene homologs, they can easily recombine one another and duplicate or remove certain $a v r B s 3$ genes. This could be plausible explanation of why Xanthomonas spp. can easily change their race patterns within a short time period.

$X$. campestris pv. campestris can infect various numbers of crucifer plants. So far, most of studies with this bacterium have been performed with strains isolated from cabbage. As reported previously (Kay and Bonas, 2009), X. campestris pv. campestris strains isolated from cabbage in Korea carry both $a v r B s 1$ and $a v r B s 2$ genes, but not $a v r B s 3$ gene. However, strains isolated from Chinese cabbage carried $a v r B s 2$ and $a v r B s 3$, but not $a v r B s 1$. Moreover, strains isolated from radish only carried $a v r B s 2$ gene. These patterns are quite different from previous reports. More interestingly, based on disease assay on crucifer plants, either avrBs 1 or $a v r B s 3$ must be present in $X$. campestris pv. campestris to cause disease on Chinese cabbage or cabbage because strains from radish can not infect either plant. This is consistent with notion that these two genes are necessary for virulence of Xanthomonas spp. (Gurlebeck et al., 2006). In addition, strains from Chinese cabbage were completely avirulent in broccoli, but strains from cabbage were highly virulent. This implies that broccoli has a recognition system for AvrBs3, but not for AvrBs1. Indeed, a mutant strain of $X$. campestris pv. campestris from Chinese cabbage can not induce the HR in broccoli, indicating that broccoli has a corresponding resistance protein like Bs3.

Rice and pepper are two major crops growing in Korea.
In our study, we found race shift in both $X$. campestris pv. vesicatoria and $X$. oryzae pv. oryzae. This indicates that high selection pressure for this shift is present in the Korean environment. Based on our study, race shift in $X$. campestris pv. vesicatoria was directional, i.e. race 3 to race 1 by acquiring avrBs 3 gene. Although many different cultivars of pepper have been bred and grown in Korea for a long time, comprehensive analysis to determine resistance patterns of those cultivars has not been done yet. However, directional race shift may indicate that many pepper cultivars growing in Korea at present do not contain $B s 3$ gene, and that is why $X$. campestris pv. vesicatoria acquires $a v r B s 3$ gene to increase its fitness on pepper plants (Leach et al., 2001). Unlike $X$. campestris pv. vesicatoria, $X$. oryzae pv. oryzae seems to remove (or mutate) certain $a v r B s 3$ gene homologs to infect certain resistance cultivars because most of cases we found were appearance of new strains that can infect resistant cultivars. Interestingly, in one case, the rice cultivar carrying xal3 gene turned resistant to some strains of $X$. oryzae pv. oryzae. This is a quite unusual pattern because those strains acquired a gene to decrease their fitness in certain cultivars, but it could be explainable if avrXa13 gene helps this bacterium increase fitness to other cultivars at the population level.

\section{Acknowledgments}

This work was supported by the Rural Development Administration fund PJ006911.

\section{References}

Alfano, J. R. and Collmer, A. 2004. Type III secretion system effector proteins: double agents in bacterial disease and plant defense. Annu. Rev. Phytopathol. 42:385-414.

Boch, J., Scholze, H., Schornack, S., Landgraf, A., Hahn, S., Kay, S., Lahaye, T., Nickstadt, A. and Bonas, U. 2009. Breaking the code of DNA binding specificity of TAL-tyep III effectors. Science 326:1509-1512.

Bonas, U., Stall, R. E. and Staskawicz, B. 1989. Genetic and structual characterization of the avirulence gene $a v r B s 3$ from Xanthomonas campestris pv. vesicatoria. Mol. Gen. Genet. 218:127-136.

Ciesiolka, L. D., Hwin, T., Gearlds, J. D., Minsavage, G. V., Saenz, R., Bravo, M., Handley, V., Conover, S. M., Zhang, H., Caporgno, J., Phengrasamy, N. B., Toms, A. O., Stall, R. E. and Whalen, M. C. 1999. Regulation of expression of avirulence gene $a v r R x v$ and identification of a family of host interaction factors by sequence analysis of avrBsT. Mol. PlantMicrobe Interact. 12:35-44.

Gurlebeck, D., Thieme, F. and Bonas, U. 2006. Type III effector proteins from the plant pathogen Xanthomonas and their role in the interaction with the host plant. J. Plant Physiol. 163:233-255. 
Hopkins, C. M., White, F. F., Choi, S.-H., Guo, A. and Leach, J. E. 1992. Identification of a family of avirulence genes from Xanthomonas oryzae pv. oryzae. Mol. Plant-Microbe Interact. 5:451-459.

Huang, N., Angeles, E. R., Domingo, J., Magpantay, G, Singh, S. Z. G, Kumaravadivel, N., Bennett, J. and Khush, G. S. 1997. Pyramiding of bacterial blight resistance genes in rice: markerassisted selection using RFLP and PCR. Theor. Appl. Genet. 95:313-320.

Jones, J. B. and Stall, R. E. 1998. Diversity among Xanthomonads pathogenic on pepper and tomato. Annu. Rev. Phytopathol. $36: 41-58$

Kay, S. and Bonas, U. 2009. How Xanthomonas tyep III effectors manipulate the host plant. Curr. Opin. Microbiol. 12:37-43.

Leach, J. E., Vera Cruz, C. M., Bai, J. and Leung, H. 2001. Pathogen fitness penalty as a predictor of durability of disease resistance genes. Ann. Rev. Phytopathol. 39:187-224.

Moscou, M. and Bogdanove, A. J. 2009. A simple cipher governs DNA recognition by TAL effectors. Science 326:1501.

Nino-Liu, D. O., Ronald, P. C. and Bogdanove, A. J. 2006. Xanthomonas oryzae pathovars: model pathogens of a model crop. Mol. Plant. Pathol. 7:303-324.

Park, H.-J., Han, S.-W., Oh, C.-S., Lee, S., Ra, D., Lee, S.-H. and Heu, S. 2008. Avirulence gene diversity of Xanthomonas axonopodis pv. glycines isolated in Korea. J. Microbiol. Biotechnol. 18:1500-1509.

Schornack, S., Ballvora, A., Gurlebeck, D., Peart, J., Genal, M.,
Baker, B., Bonas, U. and Lahaye, T. 2004. The tomato resistance protein Bs4 is a predicted non-nuclear TIR-NB-LRR protein that mediates defense responses to severely truncated derivatives of AvrBs4 and overexpressed AvrBs3. Plant J. 37:46-60.

Schornack, S., Meyer, A., Romer, P., Jordan, T. and Lahaye, T. 2006. Gene-for-gene-mediated recognition of nuclear-targeted AvrBs3-like bacterial effector proteins. J. Plant Physiol. 163:256-272.

Swords, K. M. M., Dahlbeck, D., Kearney, B., Roy, M. and Staskawicz, B. J. 1996. Spontaneous and induced mutations in a single open reading frame alter both virulence and avirulence in Xanthomonas campestris pv. vesicatoria avrBs2. J. Bacteriol. 178:4661-4669.

Van den Ackerveken, G, Marois, E. and Bonas, U. 1996. Recognition of the bacterial avirulence protein AvrBs3 occurs inside the host plant cell. Cell 87:1307-1316.

Yang, B. and White, F. F. 2004. Diverse members of the AvrBs3/ PthA family of type III effectors are major virulence determinants in bacterial blight disease of rice. Mol. Plant-Microbe Interact. 17:1192-1200.

Yang, B., Zhu, W., Johnson, L. B. and White, F. F. 2000. The virulence factor AvrXa7 of Xanthomonas oryzae pv. oryzae is a type III secretion pathway-dependent nuclear-localized double-stranded DNA-binding protein. Proc. Natl. Acad. Sci. USA 97:9807-9812. 